\title{
ANÁLISIS ARGUMENTATIVO DE CARTAS PRIVADAS DEL SIGLO XVI
}

\author{
Marta Fernández Alcaide \\ Universidad de Sevilla
}

\begin{abstract}
We have realized an analysis of the argumentatif process used in a selection of texts, private letters from the sexteenth century. We have payed attention to the morphosintactic level, but we have inquired into the lexicon. This analysis have taken us to see that these letters, in spite of thers limitations, are interactives and they had a clear persuasive purpose, even though the linguistic tools to do that sometimes are poor and restricted.
\end{abstract}

\section{INTRODUCCIÓN.}

Para la realización de este trabajo hemos seleccionado un total de diez cartas privadas del siglo XVI que se pueden encontrar en el Archivo General de Indias de Sevilla. Hemos analizado los documentos, centrándonos en los procedimientos argumentativos, especialmente los sintácticos y los léxicos, teniendo en cuenta los distintos actos de habla realizados en cada fragmento, pues partimos de la idea de que la argumentación se puede manifestar en cualquier acto de habla, sin que se restrinja a uno determinado.

Antes de pasar a detallar los resultados de dicho análisis, debemos hacer algunas aclaraciones, puesto que estas cartas son sólo una pequeña representación de un tipo concreto de texto, como es la correspondencia privada, dentro de un registro que creemos ser propio de la proximidad comunicativa, por todas las circunstancias que rodean y configuran nuestros textos: clase social de los "interlocutores", relación entre ellos, temas de los que se trata, finalidad de la comunicación, grado de alfabetización, momento histórico de gran expansión de la escritura, aparición de los primeros manuales para aprender a leer y escribir, etc.

El propósito de este trabajo es mostrar que en los distintos actos de habla, incluido el asertivo a pesar de su apariencia, podemos encontrar dimensión argumentativa, en el sentido que plantea Ducrot:

"Le sens d'un énoncé comporte, comme partie intégrante, constitutive, cette forme d'influence que l'on appelle la force argumentative. Signifier, pour un énoncé, c'est orienter" (L'argumentation dans la langue, 1983).

Es decir, creemos que hay argumentación, si no en todos, al menos en casi todos los enunciados que emitimos y en todos los actos de habla que realizamos. Esta es la tesis de la que partimos para hacer el análisis, pues, aunque aparentemente estos documentos no son 
argumentativos en su totalidad, el mero hecho, por ejemplo, de expresar la opinión acerca de las noticias recibidas en cartas anteriores es ya una forma del emisor de acercarse al receptor, es decir, eso ya es argumentación.

No olvidamos que, por ser el tipo de texto que es, no encontramos un discurso muy elaborado desde el punto de vista argumentativo, como puede serlo el discurso parlamentario, sino que se percibe la construcción del mismo a medida que se va produciendo, de manera que en estas cartas no encontramos marcadores discursivos apenas, aunque sí haya nexos subordinantes y coordinantes, de manera que hemos prestado atención a otras unidades y otros recursos argumentativos menos frecuentes.

Del mismo modo, tampoco hay un gran nivel de elaboración en la macroestructura de las cartas, puesto que responden a unos patrones prefijados: después de la salutación hay siempre alguna referencia a otras cartas recibidas o enviadas y al final, antes de la despedida, hay siempre un espacio para saludar, encomendar y recordar a otras personas, familiares y amigos. El contenido que media entre la salutación y la despedida no está tan fijado, sin embargo, parece que en todos los casos hay siempre una serie de noticias y de premisas anteriores a la petición: este esquema estaba así previsto por los manuales para escribir cartas, según podemos comprobar en el Manual de escribientes de Antonio de Torquemada:

“(...) porque conviene hazer algunas premisas y después dar algunas causas antes de venir a la petiçión (...)” (p. 184)

Y tampoco son de creación personal frases como las que siguen, que se reparten y se repiten en estas cartas:

Nuestro Señor me dexe veros como yo deseo $(2052$, N 39, 8)

Buestro verdadero tío, el que más que a sí os ama $(2053, \mathrm{~N} 126,2)$

rreçibí vna de vmd y con ella muncho contento en saber de vuestra salud (2054, N 17,3)

Vuestro marido que os desea veros más qu'escreviros $(2054, \mathrm{~N} 17,4)$

Y con esto seso, y no de rrogar a Dios que la vea yo en esta tiera $(2055, \mathrm{~N} 27,3)$

De modo que podemos ver confluir dos tendencias: una hacia el respeto de unas normas y de unos patrones que estaban en la mente de los amanuenses, bien fuera el propio emisor, bien alguien a quien él pagase para desempeñar tal ejercicio; y la otra tendencia hacia la creación individual, a pesar de que los protagonistas de estas cartas no tuviesen grandes recursos lingüísticos por ser gente con un nivel medio-bajo de alfabetización y pertenecer a la baja burguesía.

\section{PROCEDIMIENTOS ARGUMENTATIVOS.}

Hemos podido observar que estos documentos son argumentativos, a pesar de que la persuasión se realice con unos mecanismos bastante primitivos, debido al nivel sociocultural de la mayoría de los hablantes, encubriéndola, de modo que parece que los textos son la manifestación de actos de habla asertivos y directivos, cuando, en realidad, lo que parece una narración totalmente ajena a lo que se pide no es sino una serie de argumentos en favor de esas peticiones o esas órdenes, según cada caso.

En efecto, la estructura de estas cartas suele entremezclar las secuencias, predominando las narrativas y las instructivas. Veamos algún ejemplo: 
“(...) esta no sirvirá para más de para que, señora, sepáis cómo quedo bueno de salud y de lo demás quedo como quedan algunos casados acá, a sonbra de tejados, porque andamos huydos al monte porque no mos llevasen en'sta flota (...)" $(2052$, N 39, 7)

donde encontramos que estas primeras palabras de la carta por una parte están dando noticia de la situación del emisor con una secuencia narrativa y un acto de habla enunciativo; pero, por otra, esconden un argumento a la posterior petición a su mujer de que se reúna con él, porque los hombres casados que no tenían a sus mujeres en el Nuevo Mundo, después de un tiempo allí solos, eran enviados a España presos y dejando atrás la fortuna ganada.

Es sólo un ejemplo pero en él se observa lo que se produce en todas las cartas de forma recurrente: la dimensión argumentativa está siempre presente, no importa sobre qué secuencia o sobre qué acto de habla.

Otra cuestión que tenemos que abordar es que no todas las cartas de esta selección son idénticas. Efectivamente, hemos percibido una diferencia entre los documentos, destacando en este sentido los que se encuentran en los legajos 2053 y 2063, escritas de un tío a un sobrino y a una sobrina, respectivamente. El grado de confianza entre los interlocutores en estos casos es bien distinto del que se da en las demás cartas.

Esto, además de observarse en la apertura de las mismas, señor sobrino e ilustre señora, frente a señora, señora mía, señora hermana, señor hermano o hermano de mi corazón, se percibe también en las elecciones lingüísticas para persuadir, porque parece que es el empeño por parecer neutral lo realmente argumentativo en estos casos.

Es decir, estas dos cartas tienen una clara intención comunicativa, pero puesto que hay una distancia (y no nos referimos a la geográfica, claro está) entre los dos interlocutores, el emisor no puede hacer la petición de forma directa o brusca, sino que tiene que preparar a su receptor cuidando su imagen, haciendo que no se sienta violentado, sino respetado y considerado, porque es el método para lograr del receptor lo que se le pide. Por eso el emisor tiene que pedir sin hacerlo bruscamente, tiene que persuadir sin que se note que está intentando cambiar la opinión del otro.

\subsection{Procedimientos argumentativos morfosintácticos.}

Antes de empezar con los argumentos puramente sintácticos, haremos alusión a un fenómeno que no tiene cabida ni en este ni en el siguiente apartado, pero por estar relacionado con el nivel del enunciado, lo incluimos en este primer punto. Nos referimos al cambio de signo formal en un acto de habla enunciativo, es decir, la aparición de un significante negativo pero con significado afirmativo, resultando más rotundo para expresar una idea. Veamos sólo algunos ejemplos:

no deseo en esta tierra sino salud $(2051, \mathrm{~N} \mathrm{113,1)}$

para mí no pudiera ser mayor contento $(2051, \mathrm{~N} 113,2)$

no puede ser sino muy acertado y a mi contento $(2051, \mathrm{~N} 113,2)$

No ay allá cosa que pase que acá no se sabe $(2052$, N 39, 2)

Se trata, por tanto, de negar un enunciado, pero queriendo afirmar, de manera que la expresión es la negación de lo contrario de lo que se asegura en realidad. Dicha construcción resalta el término afirmado y ya hemos dicho más arriba que todo resalte 
implica la selección de la información por parte del emisor y una valoración de la misma, quedando entonces marcada por la subjetividad.

\subsubsection{Morfología verbal y pronominal.}

En algunas cartas ocurre que la subjetividad se expresa a través de las marcas de primera persona del singular, como ocurre en la 2054, N 17, donde son catorce los verbos con estas características, de los cuales cinco aparecen también con el pronombre personal correspondiente. Los catorce verbos suponen un $35,7 \%$ del total de la carta, de modo que no podemos dejarlo pasar por alto, porque implica una alta presencia del emisor en el texto, que informa y persuade al mismo tiempo. Algunos ejemplos en esta carta son:

rrecibí, yo deseo, estoy (dos veces), tengo (tres veces), rrecibiré, yo no dexe, suplico, yo lo serviré, acudiré, escrivo, quedo

Lo mismo ocurre en la 2065, N 47, donde tenemos que de los 90 que hay repartidos por todo el texto, 30 están en primera persona, y casi todos ellos en un solo párrafo, el tercero de la carta, que es donde el emisor realiza su petición. De manera que encontramos de nuevo el recurso a la primera persona para marcar desde la morfología la carga valorativa del texto.

Hay que señalar que si bien es cierto que este recurso se da de forma más patente en las dos cartas citadas, también se da en las otras, aunque, como puede imaginarse, no es así en las dos que separamos del resto en un principio, las de 2053 y 2063, en las que apenas encontramos rasgos morfosintácticos con valor argumentativo.

Otro procedimiento morfológico a favor de la persuasión es el empleo del futuro. No nos referimos a los usos de este tiempo con valor imperativo como en:

$$
\text { Diréysle (2054, N 17, 1) o darle eys }(2054, \text { N 17, 1) }
$$

sino en otros casos en los que están al servicio de la cortesía:

Servirá ésta para hazeros saber $(2054, \mathrm{~N} 17,1)$

Recibiré todo contento que con la brevedad posible os adereçéys para vuestra venida, como dicho tengo (2054, N 17, 1)

donde el futuro convierte toda la frase en un acto perlocutivo: formalmente es una afirmación pero tras ella se esconde una petición, que es otro acto de habla diferente.

\subsubsection{Nivel de la oración: algunos tipos oracionales}

En estas cartas observamos la confluencia de dos tendencias: una hacia la espontaneidad, por ser cartas privadas entre familiares, y otra hacia el formalismo, por ser de personas de nivel medio que acogían unos modelos previos. Dicha confluencia provoca, por ejemplo, la aparición de algunas oraciones relativas que más que aportar sentido al texto, actúan como muletillas formales. Extraemos algunos ejemplos:

hasta que bea carta vuestra, la qual por mí es deseada $(2053, \mathrm{~N} 126,1)$

Vuestro verdadero hermano, que vuestro bien desea $(2056, \mathrm{~N} 37,5)$

con que sienpre se acuerde de hazer bien por ellos, que lo mjsmo hago yo acá (2059, N 69, 12) 
También encontramos causales de la enunciación, construcciones directamente relacionadas con el hecho de que sean cartas argumentativas, aunque no en apariencia:

Vm le suplique al senor Pedro de Morga haga a don Francisco Selade a vs. ms. por más tiempo, que yo probeeré siempre (2051, N 113,2)

lo que suplico a Vm es que no tenga pena, y lo mesmo diga a mjs señoras Azamar y a mi hermana que bien sé que es honbre de poco estómago $(2051, \mathrm{~N} 113,2)$

qu'el señor Estorga dará todo aquello que ovierdes menester (2054, N 17, 1)

que yo lo serviré ofreciéndose en qué $(2054$, N 17, 1)

En efecto, éstas son las más abundantes y las que más claramente encierran la dimensión argumentativa, pero, como puede imaginarse, no son las únicas, pues también se detecta en las comparativas, de superioridad y de igualdad. A continuación vemos algunos de esos ejemplos, donde se muestra cómo la ponderación por parte del emisor conlleva una valoración de los elementos comparados, cuyo resultado final es el argumentativo, pues todo el enunciado se carga de subjetividad:

Pueden los hombres ganallo acá mejor que no allá $(2052$, N 39,1)

y si no fuera por vna muger que se dize Ynés Núñez, qu'es de color morena, hízome mucho rregalo, que la devo más que a mi mesma madre (2053, N 126)

porque entendía que os quedaríades en esta buena tierra y más biendo el buen aparejo de bibir en ella en más descanso que allá y con menos necesidad $(2056$, N 37, 1)

los rregalo yo aquí en este puerto de la Beracruz y los siruo (...) con mjjor voluntad que otros $(2056, \mathrm{~N} 37,2)$

En la última me avisó que hará lo que le tengo suplicado de benirse(...)Por amor de Dios le rruego no deje de acerlo, pues sabe lo que yo lo deseo y que lo pasará mejor que allá (2067, $\mathrm{N} 35,1)$

No rrepare en nada que Dios me ayudará(...), pues que Dios nos a dado aquí más que allá y podremos pasar mejor $(2067, \mathrm{~N} 35,1)$

Los seis ejemplos extraídos pertenecen a cuatro cartas diferentes, y, aunque no en todos pueda hablarse de oraciones, sí que se da en los seis la estructura comparativa. Si observamos el conjunto, notamos en seguida que esta estructura suele emplearse para la comparación entre el Nuevo Mundo y España, donde, como es natural, el término que resulta superior es el que se refiere al Nuevo Mundo, pues se consideraba como una tierra prometida, sólo llena de cosas buenas. La comparación consigue ponderar los sustantivos, marcados también semánticamente, aunque eso no corresponda a este apartado. Tenemos, entonces, varios elementos que se ponen en relación, además de las dos tierras: acá / allá, aquí / allá, más / menos, descanso / necesidad.

El segundo ejemplo es diferente de estos pues está hablando de una mujer, pero hay que advertir dos cosas: la primera es que pondera la virtud de la mujer que le ha ayudado, hasta el punto de compararla con su madre, cuando se supone que las madres hacen lo máximo por sus hijos; la segunda es más interesante porque resulta ser un argumento de algo que viene más adelante en esa carta: el emisor está ya justificando haberse casado con una india porque estaba mal visto en España, aunque no ocurría así en el Nuevo Mundo, de modo que esta comparación de superioridad ya está avanzando la idea de que los indios pueden ser igual de buenos, e incluso más, que los españoles. 
Además de los ejemplos dados de comparativas de superioridad, también los encontramos de igualdad, que extraemos ahora, aunque no revelen ninguna diferencia ni estructural ni pragmática con respecto a las anteriores:

lo e sentido tanto qual Dios me es testigo $(2051, \mathrm{~N} 113,2)$

ebitará tantos trabajos y soledad como padesçe $(2051, \mathrm{~N} 113,5)$

esta tierra tan buena es como la nuestra $(2067, \mathrm{~N} 35,1)$

En ellos se observa que es la propia construcción sintáctica la que lleva la carga argumentativa, pues confiere al enunciado un carácter valorativo. Pero también encontramos dicha construcción, no necesariamente oracional, con la conjunción como y su compuesto, como si, en los que se sublima la relación entre el emisor y el receptor de la carta, aunque, por otros rasgos que contiene, se percibe el distanciamiento entre ambos, pero es un modo de estrechar la relación para persuadirle de que realice el viaje. Nos referimos a estos dos casos:

hos digo qu'en diez años que somos casados, no emos abido ningún hijo, loado sea Nuestro Señor, y ella me da más guerra cada día, como le e dado cuenta que tengo vn sobrino que le crié esde [ni] ño y que le quiero como si fuera mi hijo. Está ella de propósito, [s]i Dios Nuestro Señor hos trae a esta tierra, de degaros nuestros bienes, los que tubiéremos, como a hijo ligítimo y eredero (2053, N 126)

Dejando ya a un lado las estructuras comparativas, nos fijaremos ahora en otras estructuras que se emplean también como procedimientos argumentativos. Nos referimos a las concesivas, de las cuales extraemos este fragmento tan significativo, si bien es verdad que dichas construcciones escasean en estos textos:

avnque quisiéredes que vuestro marido venga por ella, no se le dará avnque más poderes trayga $(2056, \mathrm{~N} 37,1)$

La primera de estas dos concesivas se expresa con futuro de subjuntivo, que es, según Lapesa $^{1}$, el tiempo de la hipótesis contingente posible. Ahora bien, al encontrarla en una oración concesiva, parece que abarque todos los supuestos posibles, de modo que la convierte en un argumento suficiente para revocar todos los contrargumentos que podrían plantearse. Esta es la razón por la cual el enunciado completo, al final, deja cierta sensación de irrealidad o imposibilidad, pero no tanto por la forma verbal de esta primera concesiva como por el conjunto de todos los elementos, ya que el obstáculo que plantea dicha subordinada no es real, es un supuesto.

Algo más frecuentes son las consecutivas. Observaremos primero algunas muestras:

no es él tan maníaco que si quisiese venjr no lo traerán $(2059$, N 69, 1)

a dado en la tierra, entre los naturales d'ella, tan gran pestilençia que no ay qujen conpre trigo ni maýs $(2059, \mathrm{~N} 69,1)$

me abía alegrado tanto que no se lo podré senyficar (2063, N 27, 1)

e sido tan desdichado que nunca e tenido más de dos cartas suyas $(2067$, N 35, 1)

\footnotetext{
${ }^{1}$ Cfr. R. Lapesa, 2000: 848.
} 
Lo primero que hay que decir respecto a ellas es que la propia construcción produce el resalte del término al que se aplica el adverbio, que en estos ejemplos son un sustantivo, dos adjetivos y un verbo. Al hacer hincapié en un término, sea cual sea la categoría gramatical del mismo, se está realizando una valoración, tras la cual se esconde la subjetividad del emisor, con la que se busca la orientación interpretativa del interlocutor, en estos casos, la persuasión del familiar de que no tendrá problema para realizar el viaje, la justificación de su ruina, la manifestación de su alegría porque había creído que los familiares habían llegado a esas tierras, y la persuasión del hermano para que le escriba. De los cuatro ejemplos que extraemos, destaca el tercero precisamente por ser el más neutral de todos, pero es que pertenece a una de las dos cartas que separamos más arriba del resto por su exceso de cortesía.

\section{1.3. Nivel de la oración: el orden de palabras}

El orden de palabras puede ser un procedimiento argumentativo desde el momento en que un orden marcado, una focalización, supone dar énfasis, resaltar, pues ese mismo contenido podría haberse expresado de otro modo, siguiendo el orden no marcado, es decir SVO. Sin embargo, el emisor prefiere otro orden.

En unos casos, la focalización nos lleva a ordenar el discurso, pues se supone que el texto es la respuesta a otro previamente recibido por el individuo que está en Indias, de manera que nos muestra que estas cartas eran interactivas, como una conversación en la que las intervenciones tenían una distancia real grande.

En este sentido, tenemos los siguientes ejemplos:

En lo de Alonso Melio ya creo quando esta escriuo abrá llegado en salbamento y bisto a Vm (2051, N 113, 1)

De la llegada de Domjngo López a casa de Vm m'e holgado mucho por el contento de Vm $(2051$, N 113, 2)

De lo que vuestra merced dize de la muerte de nuestra madre y ermanos $(2059, \mathrm{~N} 69,2)$

Del mismo tipo son otras construcciones que encontramos de forma abundante, sin que necesariamente sea a comienzo de párrafo:

porque en poder ajeno cada día valdrá menos $(2056, \mathrm{~N} 37,1)$

en qualquiera nabío que os quiráis fletar, sabiendo que es cosa mía, os traerán con todo rregalo porque todo (sic) los más de los maestros son mjs conoçidos y amigos, que los rregalo yo aquí $(2056, \mathrm{~N} 37,2)$

En el primero, tenemos una causal de la enunciación, estructura que de por sí es argumentativa, pero que, además, tiene un orden marcado: $\mathrm{CCL}+\mathrm{CCT}+\mathrm{Vb}$; con esos dos complementos refuerza con anticipación el sentido negativo del verbo que les sigue.

El segundo constituye un procedimiento argumentativo similar al anterior, aunque más complejo y más desarrollado. El esquema sería CCL en qualquiera nabío [+ Or Rel que os quiráis fletar] + CCM (Or de Gerundio sabiendo [+Or Completiva] que es cosa mía) + Principal os traerán con todo rregalo + Causal de la enunciación porque todo (sic) los más de los maestros son mjs conoçidos y amigos [+ ¿Causal de la enunciación o Relativa? que los rregalo yo aqui].

Es una oración compleja, larga, que ofrece muchos datos que pueden servir de elementos de persuasión al receptor, además de la propia construcción sintáctica, que 
resalta algunos elementos y con ellos, la tesis de este enunciado, pues todo lo que precede a la oración principal son argumentos, destacando especialmente la fuerza de los pronombres cualquiera y mía, actuando como determinante y adyacente, respectivamente, así como también todo tiene esa función en la oración principal, tras la cual vienen el argumento más evidente, que es la causal de la enunciación.

Con respecto a la duda que planteamos para el análisis del último fragmento del enunciado, debemos decir que, en efecto, no puede afirmarse que no sea una oración relativa, puesto que el que es un pronombre con referencia anafórica sin duda alguna, por más que el otro pronombre repita dicha referencia. Este fenómeno no debe extrañar pues se da en nuestra lengua desde el siglo XIII y, además, es de enorme frecuencia en el discurso oral (lo cual reforzaría la idea que sugeríamos al inicio en relación con el tipo de texto que estamos tratando). Pero también dijimos que podía analizarse como oración causal, pues, efectivamente, el hecho de que los regale y agasaje es la causa de que sean sus amigos. La ambigüedad del análisis de este segmento es otro rasgo que caracteriza lo coloquial.

Pero retomando el asunto de las focalizaciones, encontramos más a lo largo de todos los textos, sin embargo, hay otras que son más interesantes que las ya citadas. Nos referimos a estos otros casos:

lo que suplico a Vm es que no tenga pena, y lo mesmo diga a mjs señoras Azamar y a mi hermana que bien sé que es honbre de poco estómago $(2051, \mathrm{~N} 113,2)$

Lo que, senora, os rruego es que viniendo ella, que vengáis en su compañía (2052, N 39, 1)

Esta construcción focalizadora, según la profesora Fuentes, convierte el segmento en argumento de lo anterior, aunque en este caso concreto parece que ocurre lo contrario: el realce de este enunciado pone de manifiesto que es ésta la tesis del párrafo y que todo lo anterior son sus argumentos; la tesis surge como consecuencia de lo anterior y con este realce parece que la petición, en realidad, es una obviedad que casi no hacía falta explicitar.

Pero de esta estructura, lo que...es que..., hay que decir también que hoy es considerada propia de la lengua coloquial ${ }^{2}$, lo cual no se aleja de la realidad del texto ante el que nos encontramos.

Relacionada con ésta tenemos también los siguiente ejemplos:

sabe lo que yo lo deseo $(2067$, N 35, 1)

lo deseo ver lo que no podré encarecer $(2067$, N 35, 2)

Son estructuras enfáticas donde el contenido más relevante es cierto valor cuantitativo, pero este tipo de construcción se relaciona con las consecutivo-exclamativas ${ }^{3}$. El resultado es que provoca un énfasis que es, en última instancia, argumentativo; curiosamente, en los dos casos, la construcción está relacionada con el verbo desear que, por sí, es axiológico.

\footnotetext{
${ }^{2}$ En efecto, puede comprobarse en la bibliografía: C. Fuentes Rodríguez y E. R. Alcaide Lara, 2002 o A. Narbona Jiménez, 1989 y 1990, entre otros.

${ }^{3}$ Nos referimos a oraciones del tipo: "Está que se sube por las paredes", "Trabaja que un día explota", etc. donde la relación de consecuencia es más evidente, quizá, que en estos ejemplos aquí expuestos.
} 
Un solo ejemplo tenemos de otra construcción que resulta también interesante dentro de las focalizaciones:

quanto más trabajo y más me desvelo por lleuar algo, más me lo va quitando en donde él sabe $(2065, \mathrm{~N} 47,2)$

En él observamos una comparativa de desigualdad que expresa el paralelismo proporcional entre dos procesos; esta estructura se encuentra en el párrafo donde aparece la tesis de la carta, de modo que esta construcción viene a reforzar el carácter valorativo y argumentativo del fragmento.

\subsubsection{Nivel del enunciado}

En este tipo de documentos, escasean los procedimientos sintácticos que tengan un evidente valor argumentativo, de modo que podemos fijarnos en el orden, en la construcción, pero difícilmente encontramos marcadores discursivos propiamente dichos.

Pero como siempre hay excepciones, tampoco falta algún término o locución que haga las funciones de marcador. Es el caso del adverbio cierto en los siguientes enunciados:

plega a Nuestro Señor le pague todo el bien que nos a hecho y hace cada día, que cierto le somos en grant obligación (2051, N 113, 1)

en'l nauío de aujso aujsaré, que yo cierto querría conçertarme para acabar cosas (2051, N 113, 3)

yo daré horden cómo Vm y mjs hijos nos juntemos presto, que cierto esta tierra está la más perdida que nunca se a bisto $(2051, \mathrm{~N} 113,3)$

La de Vm rrecibí en fecha a diez y seys de março de ochenta y quatro y çierto que quando me la dieron que entendí que estaba Vm y su ermana en el puerto de Caballallos (sic) (2063, N 27, 3)

Ante estos ejemplos nos planteamos si dicho adverbio es un recurso léxico enfatizador o si tal vez es un marcador discursivo. Tendemos a pensar que es un marcador, pero más que un conector de tipo reconsiderativo, como a fin de cuentas, al fin y al cabo, parece que se trata de un modalizador enunciativo.

Otro posible conector es el que observamos en el siguiente ejemplo, que desarrollamos algo más para que pueda comprenderse mejor:

Por tanto, señora, allá va Pedro Belmonte por mi señora María de Herrera. Lo que, señora, os rruego es que viniendo ella, que vengáis en su conpañía y quando por ventura no vjnjere mj conpadre Gerónimo Rodríguez podéys venir con él, porqu'él lleva veynte pesos con que al presente me hallé. Vení, señora, en todo caso, porqu'esta es mi voluntad, que en'sta tierra mos yrá bien y no mos faltará todo rrecavdo, porque en fin son Yndias, pueden los honbres ganallo acá mejor que no allá, (2052, N 39, 1)

Se trata de un conector, puesto que enlaza el segundo párrafo de la carta con el precedente, que parecía ser un acto de habla asertivo, con secuencia narrativa y descriptiva. Sin embargo, al llegar a este y encontrar el conector podemos interpretar aquel no como neutral y meramente informativo, sino como argumentativo a favor de la tesis que va a explicitar en el segundo, haciendo que éste sea la consecuencia de aquél, algo que, por otra 
parte, dictaban las costumbres retóricas de la época, según podemos constatar en el ya citado Manual de escribientes.

En otra carta encontramos un conector de idénticas funciones a por tanto, aunque menos gramaticalizado que éste ${ }^{4}$ nos referimos a por eso, que abre el tercer párrafo, probando así que los dos precedentes, como en el caso citado anteriormente, eran sólo aparentemente asertivos, pues son argumentos de la tesis que se enuncia en este nuevo párrafo:

Por eso, señora hermana, no dexéis de benir vos y buestro marido en la prymera flota que se hiziere $(2056, \mathrm{~N} 37,1)$

Podríamos discutir el valor del sintagma en todo caso en el enunciado siguiente de una de las cartas:

Vení, señora, en todo caso, porqu'esta es mi voluntad $(2052, \mathrm{~N} 39,1)$

En la actualidad, dicho sintagma se considera, en ciertas ocasiones, un relacionante opositivo-concesivo. Sin embargo, en el Diccionario de Autoridades se define esta locución como 'en todo o en cualquier acontecimiento', de modo que parece que no estaba aún gramaticalizado, o al menos no había conciencia de ello. Por tanto, creo que no podemos hablar de conector, sino que habría que entenderlo literalmente.

No parece ocurrir lo mismo en este otro ejemplo que extraemos de la misma carta:

Porque en fin son Yndias $(2052$, N 39, 1)

En él, en fin parece tener el valor de al fin y al cabo o después de todo, es decir, que parece ser un conector introductor de un argumento conclusivo. Esto no nos extraña porque ya le quedan pocas líneas para hacer un cambio de acto de habla: dará los últimos argumentos que puedan persuadir a la mujer para realizar su viaje, antes de empezar un acto de habla expresivo, de saludos y encomendamientos para otros parientes que están en España.

En otras cartas aparece un marcador discursivo diferente y curiosamente en esas cartas, no hay otros marcadores, de manera que parece ser una mínima unión en éstas:

Y no se haga otra cosa porque ancí conviene que se haga, porque yo tengo acá mj caza asentada y sería con pocos tomjnes, desaviarme y no hazer nada y ancí, yo no dexe de trabajar mediante vuestra venida, y no se gasta tiempo ni tantos tomines. (2054, N 17, 1)

Aparece en dos ocasiones en este fragmento, pero con dos funciones, pues la primera vez es un adverbio modal y es la segunda cuando observamos que actúa como conector consecutivo, puesto que cierra con él los argumentos que le precedían.

Hay otros ejemplos:

Y así, pues les enbiaba con qué poder benjr, no abía de hazer otra cosa $(2063, \mathrm{~N} 27,1)$

\footnotetext{
${ }^{4}$ Menos gramaticalizado porque en por eso "el valor conectivo va en el deíctico propiamente" (C. Fuentes Rodríguez, 1996: 41)
} 
y así teng conçertado con él que aguarde a la buelta de los navíos $(2063, \mathrm{~N} 27,1)$

Y así, estoy determinado de dar mano a esta tierra y yr a morir entre essos bardales (2065, N $47,2)$

Antes de concluir el apartado de los marcadores discursivos queremos hacer alusión a un fenómeno que llama la atención:

Mire que no deje de venir (2055, N 27, 2)

mira que no deje de venir $(2055, \mathrm{~N} 27,2)$

Mire vm que, si no viene, me prenderán por casado $(2055$, N 27, 3)

y mire que no trayga manto de arnascote $(2055, \mathrm{~N} 27,2)$

Se trata del verbo 'mirar', que es empleado cuatro veces en una sola carta en esta forma de imperativo seguido de oración sustantiva de complemento directo. Beinhauer (1968) estudia el valor de la expresión mire usted, incluyéndola entre los imperativos de percepción sensorial que se emplean para iniciar el diálogo.

Sin embargo, no parece que sea éste el valor que tenga en los ejemplos anteriores: según dicen las profesoras C. Fuentes y E. Alcaide (2002), tiene otros valores como el de enfatizador de la información, el de atenuativo de inicio o también el valor de marcador de aserción rotunda, que aparece en contextos de réplica, discusión o desacuerdo.

En nuestro caso, creemos que se trata de un marcador de la enfatización, que aumenta la fuerza ilocutiva del núcleo oracional. Éste también es llamativo porque la evidencia del imperativo queda atenuada por la perífrasis y por la negación, pero a su vez, este marcador mire Vm que recupera la fuerza primera, dando efectividad al acto directivo.

\section{2. Procedimientos argumentativos léxicos}

En el léxico no hay tampoco abundancia de términos valorativos, pues es más bien la repetición y la ponderación de los elementos léxicos las que consiguen que se muestre en ellos la dimensión argumentativa. En todo caso, haremos un rápido recorrido por las clases de palabras más relevantes en este sentido para mostrar lo que decimos.

Si comenzamos por los sustantivos, observamos que en efecto, suele haber selección de términos en función del optimismo o pesimismo que el emisor quiera otorgar a su narración o a su petición. Así, por ejemplo, tenemos sustantivos como alegría, consuelo, contento, gloria, placer, que tienen una connotación positiva, de modo que con ellos el emisor puede reconocerse como evaluador del propio enunciado. En este caso, además, deben considerarse recursos argumentativos porque se insiste en ellos, se repiten con frecuencia.

También positivos, pero en otro sentido, son estos sustantivos: cámara, honor, compañia, descanso, necesidad. Con ellos, el emisor ya no pretende expresar sus sentimientos y actitudes, sino que desea persuadir a su interlocutor para que realice el viaje: la alusión al ascenso en la escala social es un argumento más para conseguir el objetivo, de ahí que se recalque la comodidad, la clase y el lujo con estos sustantivos.

Enojo, pena, soledad son la otra cara de los sustantivos anteriores, pues en estos predomina una connotación negativa, pero tal como ocurría con los primeros, es esa insistencia en los términos lo que les da dimensión argumentativa. En otros casos no es tanto el propio término el que resulta argumentativo, sino la elección que hay tras él a nivel paradigmático: trabajos, por ejemplo, creemos que es argumentativo por el hecho de que 
sea el menos marcado de los que podría haber empleado en el mismo lugar y que aparecen en otras cartas en contextos semejantes (sufrimiento, pérdidas, pena, infortunios, dolor, desventuras...); en cambio muerte sería el otro extremo de la cadena, siendo entonces el que tiene más fuerza argumentativa.

En cuanto a los adjetivos, podemos citar algunos ejemplos: el mayor [consuelo], mayor [contento], larga [cuenta], gran [obligación], muy grande [amigo], muy buena, muy recio [tiempo], muy acertado, muy honrada, muy cuerdas, desasosegado, maltratada, ausente. El interés en estas unidades léxicas no es sólo por su significado, como podría ser más específicamente en los siete últimos ejemplos citados, sino que también el orden de las mismas constituyen procedimientos argumentativos, al mismo tiempo que les otorga carácter valorativo el hecho de que estén en grado superlativo.

De los pronombres, cualquiera que sea su función, poco hay que decir pues los que sirven para la persuasión son aquellos que consiguen una ponderación del sustantivo con el que vayan ${ }^{5}$, como sucede con los siguientes: tanto [ánimo], tanto [enojo], todo el [bien], el poco cuidado, que confieren al sustantivo que les precede un matiz valorativo, lo resaltan, de modo que el sintagma cobra valor argumentativo. Más significativo resulta otro ejemplo, para el cual debemos hacer una cita más extensa:

\begin{abstract}
"Sobrino, yo rresido en México en el Tiánguez de San Juan. En las tiendas de Tegada trato en campeche y en mantas de algodón y en zera y tengo tanbién çierto trato de cacao en Soconusco. Ya, sobrino, estoi muy cargado en días y no puedo ya soliçitar. Esto querría, si Diso (sic) fuese serbido, biniésedes a esta tierra, como os e'scrito en otras cartas, para que yo descanse y vos quedásedes en este trato." (2053, N 126, 1)
\end{abstract}

Lo que nos interesa es "çierto trato de cacao". Es llamativo que mientras los otros tres productos con los que hacía negocio los menciona sin actualizador ninguno, como simples complementos verbales, en este último caso varía el esquema polisindético y paralelístico, y en lugar del verbo tratar emplea otro más general, tras el cual introduce este sintagma. Pero no sólo está marcado por ser un caso de variatio, puesto que el actualizador también lo hace.

En efecto, esos dos recursos nos invitan a pensar que el mercado del cacao era el de más prestigio entre todos los señalados, de hecho mientras los otros productos no eran exclusivamente americanos, el cacao sí, siendo, además, hasta principios del siglo XVIII un monopolio de la Corona española, que controlaba su venta entre los propios españoles. Por esto, apenas quiere mencionarlo, y atenúa el haberlo hecho con ese indefinido que le quita valor, pero que en realidad, sabiendo las circunstancias históricas, se convierte este último elemento en el verdadero argumento para que el sobrino quiera heredar todo lo que poseen sus tíos.

Algo semejante ocurre con la elección de los verbos, especialmente aquellos con los que se expresa finalmente la petición que ha llevado a la escritura de la carta. Hay una escala de verbos para hacerlo, con más o menos intensidad y más o menos fuerza argumentativa, de los cuales, en la mayoría de los casos, el emisor elige aquellos que tienen más fuerza. De

\footnotetext{
${ }^{5}$ Ya hablamos anteriormente del valor argumentativo de la abundancia de marcas morfológicas de primera persona, incluyendo la aparición de los pronombres, de modo que no insistiremos en ese aspecto.
} 
manera que si en una carta vemos rogar, topar, excusar, no podemos olvidar que son el segundo grado de una escala de sinónimos, es decir, que podría haber dicho 'pedir' y ha dicho 'rogar', 'encontrar' y ha dicho 'topar', 'evitar' y ha dicho 'excusar': esta elección entre verbos que significan lo mismo pero tienen una carga subjetiva diferente determina su valor argumentativo.

De hecho, en las cartas que separamos de las demás al inicio, la 2053 y la 2063, no encontramos ni éstos ni suplicar o encomendar, sino que se emplea encargar, mucho más débil que los anteriores, mostrando así lo que dijimos en la introducción: que en ellas lo argumentativo está en el esmero por cuidar la imagen del receptor, para que no se vea violentado.

Queda por hablar de algunas frases coloquiales, según la clasificación que de ellas hemos encontrado en el Diccionario de Autoridades. La primera de ellas es:

qu'en diez años que somos casados, no emos abido ningún hijo, loado sea Nuestro Señor, y ella me da más guerra cada día, como le e dado cuenta que tengo vn sobrino que le crié esde [ni]ño y que le quiero como si fuera mi hijo (2053, N 126)

Esta elección hace que el enunciado sea más expresivo y haya una mayor sensación de insistencia, y por tanto, que la necesidad de que se cumpla lo que se pide es mayor.

Otro ejemplo está en la primera carta, la de 2051:

y en esto no aya falta njnguna y sea con mucha diligencia, (...) que si esto no se haze, todos nos podremos poner del lodo.

En efecto, la expresión que cierra el enunciado se define en el Diccionario de Autoridades como "ofender y denostar a uno con palabras injuriosas y ofensivas". Como se ve es una frase hecha, aunque no sabemos el registro al que se circunscribía; sí parece que contiene una carga expresiva, axiológica, que la pone de relieve y hace que sea éste el argumento de más peso para que se cumpla lo que pide.

Por último, otro ejemplo de la segunda carta:

señora, sepáis cómo quedo bueno de salud y de lo demás quedo como quedan algunos casados acá, a sonbra de tejados, porque andamos huydos al monte porque no mos llevasen en'sta flota, y a esta cavsa e andado desasegado (sic) $(2052$, N 39)

De nuevo nos encontramos con que el Diccionario de Autoridades califica nuestra expresión a sonbra de tejados como frase coloquial 'encubierta y ocultamente, a escondidas'.

Son expresiones idiomáticas que, además, pertenecen a un registro coloquial, por lo cual podríamos pensar que la unión de los dos rasgos aumentaría su valor axiológico y, por tanto, su carácter argumentativo; sin embargo, si estas mismas expresiones se emplearan en un discurso de registro más alto, causarían un mayor efecto porque serían menos esperables. En estos textos, si llegamos a pensar que son procedimientos argumentativos no es tanto porque sean "coloquiales", sino porque, al pertenecer al saber popular, el receptor, que era de ese mismo ámbito, podía entender mejor y captar más rápidamente la intención del emisor. 


\section{CONCLUSIONES}

Hemos realizado un recorrido por todos los recursos que se ponen de manifiesto al servicio de la argumentación en estas cartas, hemos podido ver que la intensidad de los mismos tenía también relación con el conocimiento íntimo de los interlocutores, por eso separamos las cartas de los legajos 2053 y 2063. Por las características del tipo de texto que hemos escogido para hacer este análisis, los recursos no son muy evidentes y son escasos, de hecho, se repiten en las distintas cartas, a pesar de que son personajes diferentes, de distintas regiones, profesiones, edades, circunstancias, etc.

Sin embargo, hay algo que no podemos dejar de decir y es que todos los recursos que hemos visto utilizar en las cartas con fines persuasivos, más o menos primitivos, pero siempre efectivos, son idénticos a los que encontramos hoy en la publicidad, en el lenguaje periodístico, en el lenguaje político o en la conversación cotidiana, siendo ésta a la que más se parecen estos textos.

Efectivamente, este corpus es una muestra de la interactividad de la comunicación: aunque no tengamos grabaciones de ningún tipo de esta época, estos textos pueden ser un ejemplo, si bien precario, de dicha interactividad, a pesar de que pueda parecer que sólo existían textos literarios, judiciales, históricos, etc. pues son los que llenan nuestros manuales. De manera que, aunque no tengamos la respuesta del destinatario, en las mismas cartas hay referencias a ese tú (imperativos, vocativos, etc.), a veces encontramos alusiones a cartas anteriores y suele ocurrir también que se hable de temas consabidos, de modo que se producen elipsis y debemos extraer implicaturas.

Igualmente observamos que la dimensión argumentativa, la persuasión y la manipulación que podemos realizar ahora con la lengua, se daba también en aquella época $\mathrm{y}$, si bien hay algunos mecanismos y algunas estructuras que proceden de la retórica del momento (esquema argumentativo envolvente: argumentación, tesis, argumentación), la mayoría pervive en la lengua de hoy, siendo dichos mecanismos (focalización, intensificación, léxico axiológico, etc.) los que permanecen a través de la historia de la lengua.

\section{REFERENCIAS BIBLIOGRÁFICAS}

ANSCOMBRE, J. C. y DUCROT, O., La argumentación en la lengua, Madrid, Gredos, 1994.

CANO AGUILAR, R., <<Lenguaje 'espontáneo' y retórica epistolar en cartas de emigrantes españoles a Indias $>>$, en Th. Kotschi, W. Oesterreicher y K. Zimmermann (eds.), El español hablado y la cultura oral en España e Hispanoamérica, Frankfurt a.M., Vervuert Verlag y Madrid, Iberoamericana, 1996, 375-404.

CANO AGUILAR, R., "Presencia de lo oral en lo escrito: la transcripción de las declaraciones en documentos indianos del siglo XVI", en W. Oesterreicher, E. Stoll y A. Wesch, Competencia escrita, tradiciones discursivas y variedades lingüísticas. Aspectos del español europeo y americano en los siglos XVI y XVII, Tübingen, Gunter Narr Verlag, 1998, 219-242.

DUCROT, O., El decir y lo dicho. Polifonía de la enunciación, Barcelona, Paidós, 1986.

ESCANDELL VIDAL, M. V., Introducción a la pragmática, Barcelona, Anthropos, 1993. 
FUENTES RODRÍGUEZ, C., La sintaxis de los relacionantes supraoracionales, Madrid, Arco Libros, CLE, 1998.

FUENTES RODRÍGUEZ, C., Lingüística pragmática y análisis del discurso, Madrid, Arco Libros, 2000.

FUENTES RODRÍGUEZ, C., y ALCAIDE LARA, E. R., Mecanismos lingüísticos de la persuasión, Madrid: Arco Libros, 2002.

LAPESA, R., "Morfosintaxis histórica del verbo español" en Estudios de morfosintaxis histórica del español, Madrid: Gredos, 2002, vol. II, págs. 730-885.

LO CASCIO, V., Gramática de la argumentación, Madrid: Alianza, 1998.

NARBONA JIMÉNEZ, A., Sintaxis española: nuevos y viejos enfoques, Barcelona: Ariel, 1989.

NARBONA JIMÉNEZ, A., Las subordinadas adverbiales impropias en español, Málaga: Librería Ágora, 1990, vol. II

OESTERREICHER, W., <<El español en textos escritos por semicultos. Competencia escrita de impronta oral en la historiografía indiana >>, en J. Lüdtke (comp.), El español americano en el siglo XVI, Frankfurt a. M. y Vervaert, 1993, 155-190

OESTERREICHER, W., $<<$ Lo hablado en lo escrito. Reflexiones metodológicas y aproximación a una tipología $>>$, en Th. Kotschi, W. Oesterreicher y K. Zimmermann (eds.), El español hablado y la cultura oral en España e Hispanoamérica, Frankfurt a. M. / Madrid: Vervuert / Iberoamericana, 1996, 317-340

SEARLE, J., Actos de habla, Madrid, Cátedra, 1980.

TORQUEMADA, A. de, Manual de escribientes, 1574, ed. de Ma Josefa C. de Zamora y A. Zamora Vicente, Madrid: Anejos del boletín de la Real Academia Española, 1970.

\section{APÉNDICE: EL CORPUS}

\section{IG 2051, N113}

\section{Señora mía:}

La última de Vm de 14 de hebrero rresçibí y con ella el alegría e consuelo/ ${ }^{1}$ que deuo rresçiujr, siendo de aquella a quien, en esta bida, más amo y esto ${ }^{2}$ no peresçerá hasta la muerte. Y no me lo agradezca Vm, pues de lei deujna/ ${ }^{\beta}$ y vmana estoi obligado a ello, y así suplico a $\mathrm{Vm}$ que con qualquier nabío/ ${ }^{4}$ que benga, tenga quenta de escrebirme, que este es el mayor consuelo que tengo. $/^{5}$

Beo la pena que Vm a tenido y sentido de mis trabaxos, que d'ello me ${ }^{6}$ pesa a mí mucho, que de lo que $\mathrm{Vm}$ padece me duelo yo, y de mis hijos, que ${ }^{7}$ de mí no ai de qué, que para ello nasçí y los honbres tienen /otros desaguaderos $/^{8}$ que las mugeres, specialmente abiendo pobeza, pero pues nuestros pecados $/{ }^{9}$ lo causan rresta dar gracias a Dios por todo, qu'el sabe por qué lo haçe. $/^{10}$ No deseo en esta tierra sino salud, para poder permanecer en servicjo de ${ }^{11} \mathrm{Vm}$, dándole contento, y dar rremedio a lo que $\mathrm{Vm}$ en mi avsencia/ ${ }^{12}$ padesca 
y así debe Vm rrogárselo y, pues que Vm la tiene, el/ ${ }^{13}$ contento d'esto será causa para que sea servjdo Dios de que yo la tenga, $/{ }^{14}$ la qual al presente no me falta. $/^{15}$

En lo de Alonso Melio, ya creo quando esta escriuo abra llegado en salba- $/{ }^{16}$ mento y bisto a Vm y pues que así es, él tendrá dado larga quenta ${ }^{17}$ de su bida y avn de la mía y a esta causa, no tengo qué rresponder. $/^{18}$

Beo, señora, que Vm habló al señor Pedro de Morga, para que me diese negocios, y que le dio $/{ }^{19}$ la palabra de hacer lo que pudiese por mí y así creo lo hará, $/{ }^{20}$ porqu'es honbre que lo suele hacer y mui de beras, plega a Nuestro Señor le ${ }^{21}$ pague todo el bien que nos a hecho y hace cada día, que cierto/ ${ }^{22}$ le somos en grant obligación, y espántome de $\mathrm{Vm}$ tener tanto ánimo ${ }^{23}$ para atreberse a decírselo, pero la necesidad es maestra de todas $/{ }^{24}$ cosas, sea Dios loado por todo, ello fue muy bien dicho y acertado. $/^{25}$ Yo le e escrito agradeciéndoselo y se lo pagaré lo que gastare con ${ }^{26} \mathrm{Vm}$, dándome Dios salud, que lo demás no basto yo a pagárselo/ ${ }^{27}$ con obras, si no es con buena boluntad y amor. $/^{28}$ (Fol. 1)

Eme holgado mucho de que mi señora Ana de Açamar y mi hermana se ayan benido a la/ ${ }^{1}$ conpanía de $\mathrm{Vm}$, que para mí no pudiera ser mayor contento, que por ${ }^{2} \mathrm{mj}$ alma juro que el no estar juntas lo e sentido tanto qual Dios me es testigo, $/^{\beta}$ que si fuera posible luego dexar los negocios y yrme lo hiciera. Resciuí/ ${ }^{4}$ tanto enojo que no pudo ser más, pero pues tan bien lo an rremediado, $/^{5}$ la pena se me tornó en gloria. Yo le escribo sobr'ello agradeciéndoselo $/{ }^{6}$ y así tendrán la quenta que siempre, que si Dios me da salu[d], yo les $/^{7}$ ayudaré a llebar mucha parte de sus trabaxos, que Dios sabe a lo/ ${ }^{8}$ que me llegan, y así la casa. Vm le suplique al senor Pedro de Morga $/^{9}$ haga a don Francisco Selade a vs. ms. por más tiempo, que yo probeeré ${ }^{10}$ siempre. En lo de Vzeda yo, como honbre que deseaba el rremedio $/{ }^{11}$ de Vm por todas bías, le escrebí, de lo qual me a pesado mucho/ $/ 2$ pero, pues que es hecho paciencia, lo que suplico a $\mathrm{Vm}$ es que no ten- $/^{13}$ ga pena, y lo mesmo diga a mjs señoras Azamar y a mi hermana que bien $/{ }^{14}$ sé que es honbre de poco estomago, y no ai para qué tratar más d'e- $/^{15} 110$, antes le es de agradecer. $/^{16}$

Yo e bisto la carta que Vm me ynbió de mj hermano Diego Hortiz y e rreci- $/{ }^{17}$ bido tanta alegría con ella, que no lo puedo encarecer, especialmente ${ }^{18}$ siendo la primera que d'él rresçibi. En ser cosa de $\mathrm{Vm}$ me huelgo más $/{ }^{19}$ que si fuera mía propia y así lo a de creer $\mathrm{Vm}$. Muchas cosas me ${ }^{20}$ escribe, holgara mucho ber las cartas que escribió a mj señora Azamar ${ }^{21}$ porque me apunta algunas cosas, para poder rrespondelle a/ ${ }^{22}$ ellas yo le rresponderé por esta otra Mar del Sur, que dende ${ }^{23}$ que llegué a esta tierra l'e escrito dos cartas, y no sé si an ${ }^{24}$ llegado a su poder. Plega a Dios las aya encaminado. Eme/ ${ }^{25}$ holgado mucho con su salud aunque me pesa de sus trabaxos. $/^{26}$

Beo aber cobrado las çédulas que dexé, que está bien. Las bi- ${ }^{27}$ sitas de los amjgos míos, beo el poco cuidado, specialmente de casa ${ }^{28}$ del señor Juan Muñoz, que estaban mas obligados a ello. Vm les pague ${ }^{29}$ en la misma mioneda (sic), que bástales ser gente de Triana, que ${ }^{30}$ no tienen çimiento en la cabeça nj tienen el decoro que se deue ${ }^{31}$ guardar. Yo le escribo a mi señora dona Catalina e de tal ma- ${ }^{32}$ nera, que a de dar al diablo al gallego y le agradezco mu- ${ }^{\beta 3}$ cho a Lope de Barral el cuidado que tiene de esa casa, Dios ${ }^{34}$ se lo pague, que si Dios me da salud no le perderá. $/^{35}$

De la llegada de Domjngo López a casa de Vm, m'e holgado/ ${ }^{36}$ mucho por el contento de $\mathrm{Vm}$ y beo el rregalo que se le hizo, ${ }^{\beta 7}$ que lo tengo en mucho, que sastisfecho estoi que $\mathrm{Vm}$ a mjs $\operatorname{cosas}^{38}$ las tiene en'l grado que las birtudes de Vm lo rrepresentan/ ${ }^{39}$ y así lo 
haga siempre, que no se pierde njnguna cosa. Abra ${ }^{40} \mathrm{Vm}$ oydo hartas neçedades d'él e ystorias de la Florida. Yo/ ${ }^{40}$ holgárame que, pues estubo tan cerca desta tierra, que hubiera ${ }^{41}$ llegado a ella, que ansí lo an hecho otros, pero más me e ${ }^{42}$ (Fol. 2) holgado de que aya buelto en saluamento. Bien creo del suçeso que después $/^{1}$ d'él a abido, me abrá $\mathrm{Vm}$ abisado en la flota que agora se spera. $/^{2}$

En'l nabio que fue de Pedro Martín que fue de aujso en'l ano de 1566 enbié a Vm/ $/ 3$ por mano de Cristóbal Escudero 600 rreales en plata, que no tengo/ ${ }^{4}$ aujso del rresciuo, más de qu'el dicho Alonso Martín, qu'es portador d'esta, me ${ }^{5}$ dixo auerlos dado al senor Pedro de Morga, del qual estoi cierto los abra ${ }^{6}$ dado a Vm. Así mesmo, ynbié en la flota de Juan de Belasco con $/^{7}$ Bartolomé Farina 400 rreales, que quando los ynbié no tenía más. $/^{8} \mathrm{Vm}$ me abise del rrescibo, no ynbio con el dicho Martín njnguna $/{ }^{9}$ cosa por que ba en muy rreçio tiempo y se temen de la llegada. Pla- $/{ }^{10}$ ciendo a Dios, en el nabio de aujso que fuere d'esta flota que agora se $/^{11}$ espera, se ynbiará lo que pudiere y juro a Dios, señoras, que hago más $\mathrm{de} /{ }^{12}$ lo que puedo y que me enpeño por probeer a Vm esa mjse- $/{ }^{13}$ ria, hasta que los negocios se mexoren, que placerá a Dios que por $/{ }^{14}$ alguna bía se engrosen, para que yo pueda dar algún descanso a ${ }^{15}$ vs. mds. Yo e acabado las quentas con Rodrigo de Quesada, bís- $/{ }^{16}$ pera de la magdalena, y le alcançé en setenta e dos mjll e $/{ }^{17}$ ochoçientos pesos, y d'ellos hasta agora no e cobrado blanca, nj la/ ${ }^{18}$ espero cobrar tan presto, y deue más de 40 mil pesos al cuerpo, él $/{ }^{19}$ está en la cárcel y andamos en concierto, no sé lo que será de lo $/{ }^{20}$ que fuere: en'l nauío de aujso aujsaré, que yo cierto querría conçer- ${ }^{21}$ tarme para acabar cosas, que si no me conçierto, ello ba muy ${ }^{22}$ a la larga y si así es, yo daré horden cómo Vm y mjs hijos ${ }^{23}$ nos juntemos presto, que cierto esta tierra está la más $/{ }^{24}$ perdida que nunca se a bisto. $/ 25$

De que Blasillo ande a l'escuela me e holgado mucho y, por amor/26 de Dios, que le azoten si hiciere por qué, y no se la perdonen por- $/^{27}$ que no s'haga vellaco, al qual y Aldonça me abraçen y besen, ${ }^{28}$ y a Juanylla la castiguen y miren por ella, porque la tengo en ${ }^{29}$ lugar de hija y así, prometo de hacer lo que deuo si ella es la que deue ${ }^{30}$ y no tira adonde biene. A mjs señoras Ana de Azamar y mj hermana ${ }^{\beta 1}$ beso las manos y avnque les escribo aparte, pueden tener ${ }^{32}$ ésta por suya. A mj señora dona Eluira Martel y la señora Ana ${ }^{33}$ delos Ríos beso las manos y que las cartas yo las e dado $/^{34}$ al secretario Cueba, muj grande amjgo de su padre, y llegaron ${ }^{35}$ a su poder, qu'está por alcalde mayor de vna gobernación d'esta ${ }^{36}$ Nueba Spana, e procurando la rrespuesta, no me la an dado, enbiarse $/^{\beta 7}$ a en'l de aujso o en la flota primera que de aquí saliere $/^{\beta 8}$ y me encomjendo en sus oraciones. Del casamjento de Espinosa me huel- ${ }^{39}$ go mucho, y que Dios la dexe gozar d'él. A ella y a las demás ${ }^{40}$ que por carta Vm me abisa, beso las manos y a la señora María Arias que $/^{41}$ (Fol. 3) si Lorenzo Núnez pone tienda y se a examjnado y tendrá $/{ }^{1}$ bien que haçer y que me beo en trabaxo para correxillo, Nuestro Señor ${ }^{2}$ nos dexe ber en esa Spaña con el contento que $\mathrm{Vm}$ desea/ ${ }^{\beta}$ y yo querría y la conserue en su santo servjcio. De México, $18 /^{4}$ de septiembre de 1567 años.

Quexoso estoi del senor Jhoan Sánchez $/{ }^{5}$ porque no me escribe, holgarmeía saber cómo está. ${ }^{6}$

La de arriba es copia de otra que a Vm escriuí en'l nauío de aujso, y lo que de nuebo/ ${ }^{7}$ se ofrece es que yo estoy bueno de salud, a Dios gracias, y con gran deseo de verme con ${ }^{8}$ Vm y con sus hijos. Plega a Dios me lo cunpla. $/^{9}$ 
Veo lo que Vm dize auerse mudado a Triana junto con el señor Francisco de Nabeda,,$^{10}$ por orden suya y del señor Pedro de Morga, de que me he holgado, y sienpre que $\mathrm{Vm} /{ }^{11}$ se guíe por tan buenos consejos no puede ser sjno muy açertado y a mi contento: ${ }^{12}$ Djos les pague las buenas obras que sinpre nos hazen. Pésame mucho la so- $/^{13}$ ledad que Vm pasa, aunque la buena bezindad será muy gran parte para ${ }^{14}$ que no aya tanta, pero con esta jornada se acabará, pues enbío por $\mathrm{Vm}$. / $^{15}$

Al señor Francisco de Nabeda y al señor Pedro de Morga y a Juan Gallego y Francisco $/{ }^{16}$ Rebolo, vezino de Vm, enbío poder, el qual ellos lo lleban para traer ${ }^{17}$ a Vm y a mjs hijos y a Juanjlla delante, con los quales ${ }^{18}$ dicho Juan Gallego y Rebolo enbío a Vm 300 pesos y otros poquytos $/{ }^{19}$ que se an de cobrar en'sa Triana, segund la larga rrelación que d'ello doy ${ }^{20}$ al señor Nabeda, los demás los rrepartirá Vm: los 100 pesos en pagar ${ }^{21}$ alqujleres y algunas deudas que $\mathrm{Vm}$ deuerá, y los otros para/22 matolaje, y los otros 100 para rropa, segund la memoria que es con esta, ${ }^{23}$ así hará $\mathrm{Vm}$, que el flete acá lo pagaré yo y le darán cámara/ ${ }^{24}$ en que venga muy a su plazer, que con qualqujer de los dos, es gente muy $/^{25}$ honrrada, podrá Vm benjr, y si pudiere con Rebolo, sea antes ${ }^{26}$ que con otro, aunque con qualquier d'ellos será açertado. A ellos ${ }^{27}$ les escriuo que fagan en ello lo posjble, y lo mjsmo al señor secretario. $/^{28}$ Todo el hato benderá, ecepto el pano de grana, si es bibo, y los colcho- $-^{29}$ nes en que ha de venjr. Y mjre Vm que las mugeres de la hedad ${ }^{30}$ de $\mathrm{Vm}$ pierden mucho punto en la nabegación de Yndias, si no son ${ }^{\beta 1}$ muy cuerdas y mjran mucho en qujtar las ocasiones: en esto/ ${ }^{32}$ no tengo qué dezille, pues que $\mathrm{Vm}$ vien lo entiende y se presçia/ ${ }^{33}$ vien del honor. De todo esto, Vm buen consejo en'1/34 señor secretarjo y en'l dicho Rebolo y Juan Gallego los quales ${ }^{35}$ darán en todo la horden que conbenga, que si Djos nos da salud, acá pasa- ${ }^{36}$ remos mejor la bida que en esa tierra y con menos trabajo. Y no ${ }^{37}$ rrehúse Vm la benjda, pues que tanto va en ella y la nabegaçión ${ }^{38}$ (Fol. 4) de benjda es muy buena, como benga por vía derecha. Plega a $/{ }^{1}$ Nuestro Señor de traella en salbamento y pluguiera a él yo pudiera $\mathrm{yr} /{ }^{2}$ por $\mathrm{Vm}$, que lo hiziera harto de mejor gana que quedarme acá por ${ }^{3}$ dalle a Vm contento, pero no puedo. Luego que esta llegue, $/^{4}$ $\mathrm{Vm}$ negocie con el señor secretario despachen a la corte para que me porro- $/^{5}$ guen el térmjno de la estada aquí por casado, y venga esta liçençia $/{ }^{6}$ por todas vías que venga nauío o nao de esas partes, porque no me/ $/^{7}$ molesten mjentras que $\mathrm{Vm}$ viene, y en esto no aya falta njnguna $/{ }^{8}$ y sea con mucha diligencia, quel dicho Francisco Rebolo ayudará a ne- $/^{9}$ gociallo y Vm dará el dinero que fuere menester, que será poco, ${ }^{10}$ que si esto no se haze, todos nos podremos poner del lodo. Y así con esto, $/{ }^{11}$ y con la buena benjda de Vm ebitará tantos trabajos y soledad como/ $/ 2$ padesçe. $/^{13}$

Ayer me conçerté con esta ciudad de México en que me an hecho deposytario del pan $/{ }^{14}$ del pósyto y que lo rreparta, y me valdrá cada un ano agora 1 mil pesos $/{ }^{15}$ y más, y adelante se engrosará y baldrá más, y otras cosas que con el $/{ }^{16}$ fabor de Dios y del físcal y del dotor Puga, que son gallegos, y ellos me an $/{ }^{17}$ persuadido a que enbíe por Vm. Estoi opuesto a vna rrelatoria: ${ }^{18}$ creo saldré con ella. $/^{19}$

Estando escriuiendo esta, llegó Lorenço Nunez de los Çacatecas, el qual venía con de${ }^{20}$ termjnaçión de yrse por su muger y llegó tarde para poderse despachar. Ame dicho/ ${ }^{21}$ en(sic) le haga venjr a su muger e yo se lo he prometido. Para que ella venga, enbía ${ }^{22}$ çien pesos que van juntamte con los que enbío a Vm, los quales lleba/23 Juan Gallego en partida de 30 maravedís 6 os(sic) de plata. Vm los rresciua y se los dé y benga/ ${ }^{24}$ juntamente con Vm y en su cámara, y alárguese más la cámara, que yo ${ }^{25}$ me huelgo mucho que $\mathrm{Vm}$ traiga 
conpanía con que entretengan el tiempo. ${ }^{26} \mathrm{Y}$ vendrán bien acomodadas, y así los señores Juan Gallego y Rebolo lo aco- $/^{27}$ modarán y aunque la cámara en que vinieren coste más $\mathrm{X}$ $\mathrm{o}$ XX ducados ${ }^{28}$ tómese a plazer y bengan descansadas, y en esto no haya falta, pues ${ }^{29}$ que acá se han de pagar los fletes y en el matalotage se abernán como les ${ }^{30}$ paresçiere y la mesma horden se tenga en despachalla en la contratación ${ }^{31}$ que con $\mathrm{Vm}$, y en esto no haya falta, porque con el rresto desta/ ${ }^{\beta 2}$ partida y los 157 pesos 7 tomines que lleba Rebolo, abrá con que Vm se pueda des- $/^{33}$ pachar a su plazer. Y porque no sirbe de otro, Nuestro Señor le dé a Vm buen $/^{34}$ biage como deseo e yo querría. De México, de abril de 1568 años.

Berdadero esclabo de Vm.

Juan López de Sande (Fol. 5)

\section{IG 2052, N39}

(De Antonio de Aguilar a su mujer Juana Delgada, en Sevilla. Parece coincidir la letra de la firma con la de la carta, por tanto, ésta sí sería de su mano.)

Señora:

Porque con mi conpadre Gerónimo Rodríguez le tengo escrito largo, $/^{1}$ esta no sirvirá para más de para que, señora, sepáis cómo/2 quedo bueno de salud y de lo demás quedo como que- $/ 3$ dan algunos casados acá, a sonbra de tejados, $/^{4}$ porque andamos huydos al monte porque no mos $/^{5}$ llevasen en'sta flota, y a esta cavsa e anda- $/^{6}$ do desasegado (sic) porque aquí enbían mucha jente $/^{7}$ presa y maltratada. En yéndose esta flo- $/^{8}$ ta, luego porné mj tienda aquí, porque sien- $/^{9}$ pre ay mucho que haser y me yrá bie[n], con a- $/^{10}$ yuda de Dios.

Por tanto, señora, allá/ ${ }^{11}$ va Pedro Belmonte por mi señora María de Herrera, $/^{12}$ porqu'él queda tanbién avsente. Lo que, señora, $/^{13}$ os rruego es que viniendo ella, que vengáis en $\mathrm{su} /{ }^{14}$ conpañía y quando por ventura no vjnjere $/{ }^{15} \mathrm{mj}$ conpadre Gerónimo Rodríguez podéys venir con él, $/{ }^{16}$ porqu'él lleva veynte pesos con que al presente $/{ }^{17}$ me hallé. Vení, señora, en todo caso, porqu'esta ${ }^{18}$ es mi voluntad, que en'sta tierra mos yrá bien $/{ }^{19}$ y no mos faltará todo rrecavdo, por- ${ }^{20}$ que en fin son Yndias, pueden los honbres $/{ }^{21}$ ganallo acá mejor que no allá, (Fol. 7) y en el navío de aviso que vjnjere, me puede $/^{1}$ escrevir cómo viene y quándo, porque lo sepa, $/^{2}$ y todo quanto allá se consertare de fle- $/^{\beta}$ tes y lo que allá pusieren, yo lo conpliré $/^{4}$ acá. A mis señoras doña Leonor y doña Juana $/^{5}$ y doña Violante les beso las manos y qu'esta ayan $/{ }^{6}$ por suya. A la señora Juana de Medina y Ana de los Re$\Gamma^{7}$ yes, mi hermana, beso las manos y a la senora vuestra coma- $/^{8}$ dre le dé mis encomiendas y que por qué me a dexado $/{ }^{9}$ d'escrevir, que si falta papel y tinta, y que mucho/ $/{ }^{10}$ me pesó de la desgraçia de Calderón. $/^{11}$

Señora, acá me an dicho algunos amigos míos que $/{ }^{12}$ os an topado en la calle muchas veses, escusaldo ${ }^{13}$ porque no ay allá cosa que pase que acá no $\mathrm{se} /{ }^{14}$ sabe. Y, contento, Nuestro Señor me dexe/ ${ }^{15}$ veros como yo deseo. De la Veracruz a xxvj de/ ${ }^{16}$ abril 1568 años. $/^{17}$

De vesto marido

Antonio de Aguilar (Fol. 8) 


\section{IG 2053, N126}

Señor:

sobrino, en otras cartas os e'scrito abisand'os adónde $/{ }^{1}$ estoi y cómo me ba y lo mesmo haré hasta que bea carta vuestra, la qual $/^{2}$ por mí es deseada. Después que de vos y de nuestros debdos me $/ 3$ aparté, e pasado muchos y deversos trabajos y, como bistes, $/^{4}$ bine en la nao de Felipe Boquín, el qual en la Veracruz, qu'es ${ }^{5}$ puerto d'esta tierra de la Nueba España, me ${ }^{\beta}$ bendió quanto $/{ }^{6}$ tenía para pagarse quarenta ducados que le devía y yo llegué ${ }^{7}$ a la muerte, y si no fuera por vna muger que se dize Ynés ${ }^{8}{ }^{N}$ Núñez, qu'es de color morena, hízome mucho rregalo, que la devo/ ${ }^{9}$ más que a mi mesma madre a la qual, si Dios os trugere con bien, $/{ }^{10}$ procuraréis de hir a su casa, porque yo la tengo avisada..$^{11}$

Sobrino, yo rresido en México en el Tiánguez de San Juan. En las $/{ }^{12}$ tiendas de Tegada trato en campeche y en mantas de algodón $/{ }^{13} \mathrm{y}$ en zera y tengo tanbién çierto trato de cacao en Soconusco. $/{ }^{14} \mathrm{Ya}$, sobrino, estoi muy cargado en días y no puedo ya soliçitar. $/^{15}$ Esto querría, si Diso (sic) fuese serbido, biniésedes a esta tierra, $/{ }^{16}$ como os e'scrito en otras cartas, para que yo descanse y vos $/^{17}$ quedásedes en este trato. Caséme en esta tierra con vna muger $/{ }^{18}$ muy a mi boluntad $\mathrm{y}$, anque allá os parezerá cosa rreçia en $/{ }^{19}$ aberme casado con hindia, acá no se pierde honrra ninguna/ ${ }^{20}$ porqu'es vna naçión la de los hindios tenida en mucho y más, $/^{21}$ hos digo qu'en diez años que somos casados, no emos abido/22 ningún hijo, loado sea Nuestro Señor, y ella me da más guerra cada día, ${ }^{23}$ como le e dado cuenta que tengo vn sobrino que le crié esde $/^{24}$ [ni] ño y que le quiero como si fuera mi hijo. Está ella de propósito, ${ }^{25}$ [s]i Dios Nuestro Señor hos trae a esta tierra, de degaros nuestros bienes, ${ }^{26}$ los que tubiéremos, como a hijo ligítimo y eredero, porque, ${ }^{27}$ después de nuestros días, querryemos tener acá quien hiziese ${ }^{28}$ bien por nuestras ánimas. Y si pudiésedes traher acá vuestro ${ }^{29}$ primo Pedro López, hijo de Catalina López, nuestra parienta, porque ${ }^{30}$ su hofiçio en esta tierra ganara quanto quisiere, quantimás ${ }^{\beta 1}$ que no lo abrá menester porque yo tengo para mí y para ${ }^{\beta 2}$ ellos, loado sea Nuestro Señor. ${ }^{\beta 3}$ (Fol. 1)

Señor sobrino, buelb'os a encargar esta benida, qu'es ${ }^{1}$ cosa que os ynporta muy mucho y no se os pongan por $/^{2}$ delante las tierras tan rremotas y apartadas del $\beta^{3}$ natural y los trabajos que en estos caminos suelen aber, $/^{4}$ sino al descanso que acá tendréis. Y si hiziéredes esta $/{ }^{5}$ mudanza, en Sebilla os darán buen rrecado, como sea para ${ }^{6}$ benir acá: Alonso Moreno, mercadel, porque yo lo traté $/^{7}$ con él quando fue de acá y se lo e'scrito tanbién y sé que ${ }^{8}$ os abiará muy bien y si pudieredes benir en la nao del señor ${ }^{9}$ Antón Sánchez, es vna persona a quien yo e hecho ser- $/{ }^{10}$ biçios y, sabiendo el parentesco que ay de por medio, ${ }^{11}$ seréis bien tratado.

A todos me darés mis besamanos $/{ }^{12}$ y ésta tengan por suya, y entiendan que si agulno (sic) $/{ }^{13}$ aposentare por esta tierra que no le faltare, con el $/{ }^{14}$ ayuda de Nuestro Señor.

Mi muger, Mari Hernández, se os encomienda mucho y os encarga lo mesmo que yo, por- $/{ }^{15}$ qu'es grande el deseo que tiene de veros en esta $/{ }^{16}$ tierra. Nuestro Señor hos guarde y os dege ber como de- $/{ }^{17}$ seo.

Fecha a diez días del mes de hebrero $/{ }^{18}$ del año del Señor de mill e quinientos y setenta $\mathrm{y} /{ }^{19}$ vn años. $/^{20}$

De México para todo lo qu'os cun- $/^{21}$ pliere.

Buestro verdadero tío, el que ${ }^{22}$ más que a sí os ama. ${ }^{23}$ 
Andrés García (Fol. 2)

\section{IG 2054, N17}

\section{Señora:}

rreçibí vna de vmd y con ella muncho contento en saber de vuestra sa- $/^{1}$ lud y de mi hija, y ancí mjsmo de los señores mys hermanos y hermanas. Plega/ ${ }^{2}$ a Nuestro Señor que dé a todos la salud que yo deseo. $/^{3}$

Servirá ésta para hazeros saber cómo el portador d'ésta, $/^{4}$ ques Álvaro d'Estorga $\mathrm{d}^{\prime}$ Estorga, vezino d'esta civdad de México, $/^{5}$ persona que va para bolver luego, lleva mj poder para que $/{ }^{6}$ pueda fletaros y para pagar todo lo que se rrecreciere $/{ }^{7}$ para vuestro aviamjento a esta civdad, el qual lo lleva para que con $/{ }^{8}$ un onbre cazado con su mujer vengáys en so conpañía. $/{ }^{9}$ Estoy acá obligado a todo aquello que él os diere o gastare, $/^{10}$ para lo que dicho tengo por ésta. Recibiré todo contento que, ${ }^{11}$ con la brevedad posible, os adereçéys para vuestra ve- $/{ }^{12}$ nida, como dicho tengo, qu'el señor Estorga dará todo aquello que $/{ }^{13}$ ovierdes menester. Y no se haga otra cosa porque ancí convie- $/^{14}$ ene que se haga, porque yo tengo acá mj caza asentada/ ${ }^{15}$ y sería con pocos tomjnes, desaviarme y no hazer na- $\left.\right|^{16}$ da y ancí, yo no dexe de trabajar mediante vuestra venida, $/{ }^{17}$ y no se gasta tiempo ni tantos tomines.

A Cristóval de Salas, $\mathrm{mj} /{ }^{18}$ hermano, suplico sea parte para vuestro aviamiento, que yo lo serviré $/{ }^{19}$ ofreciéndose en qué, y diréysle que, en los tomines que dexó Francisco/ ${ }^{20}$ de Salas, su hijo, ay acá vna escritura que devía el moço de trezien- $/^{21}$ tos pesos, y es muy poco más lo que puede rrestar; la justicia entendió $/ 22$ en ello y ándase cobrando; yo estoy de por medio, que, cobrados ${ }^{23}$ que sean, aqudiré con lo que fuere, poco o muncho, y por estar ${ }^{24}$ el portador d'esta tan de priesa no l'escrivo, que su merced aya $/{ }^{25}$ ésta por suja, y porque otro no se ofrese, quedo con confi- $/ 26$ ança que no haréys otra coza, que ancí conviene. $/^{27}$ (Fol. 3) Darle eys a leer esta carta a mj hermano Cristóval de Salas, para $/^{1}$ que vea lo tocante a su hijo. Fecha en México, a $22 \mathrm{de} /{ }^{2}$ abril de 1572 años. $/^{3}$

Vuestro marido que os desea veros más qu'escreviros

Pedro Martín, curtidor (Fol. 4)

\section{IG 2055, N27}

Señora mía:

Esta es para hazrosaber a $\mathrm{Vm}$ cómo $/^{1}$ me hazen quedar por esta tiera donde $/^{2}$ es el señor Francisco Hernandes d'Ávila y/ ${ }^{3}$ Alonso d'Ávila y Diego d'Ávila en $/^{4}$ lo qual he hallado comodo muy bueno, $/^{5}$ que es hallar una tienda con todos $/^{6}$ sus rrecados y unegro, donde pien- $\digamma^{\top}$ so ganar de comer, mediante Dios, y es- $/^{8}$ to será, si Vm estuviere en esta tiera, más, $/^{9}$ si no, todo se lo lleva el diablo, señora mía. $/^{10}$

Aý embío siem pezos, que son cada peso ocho $/{ }^{11}$ rreles, y van encaminados en casa de Gon- $/^{12}$ salo de Villaruvia, mercader, y esto $/{ }^{13}$ bien lo sabe la casa el señor Salvador d'Á- $/^{14}$ vila. Señora, yo de mi parte se lo suplico mun- $/^{15}$ cho, y la señora Ana de Villarruuia y el/ ${ }^{16}$ senor Francisco Hernandes d'Ávila, de que $\mathrm{Vm} /{ }^{17}$ venga por estas partes, porque si no, se${ }^{18}$ rá para más perdisión mía. Señora, yo afe- $/^{19}$ yto los frayles de San Agustín, que me 
dan $/{ }^{20}$ ciento y veynte pesos cada año, que son estos ${ }^{21}$ buenos prensipios y más otros comventos ${ }^{22}$ de alderredor de México, señora mi (sic). $/^{23}$ (Fol.1)

Mire que no deje de venir por ninguna $\operatorname{cosa} /^{1}$ ni se le pongan por delante nada y esto dize ${ }^{2}$ Alonso d'Ávila, que venga Cristóbal con ella, señora. $/^{3}$ Mi señor y mi padre me harán mersed $/ /^{4}$ de negociayo y allá va Hernando Botello y $/^{5}$ mi maeso, que vendrá muy a su gusto,${ }^{6}$ como si yo viniera. Señora mía, mira que $/^{7}$ no deje de venir por ninguna manera, $/^{8}$ porque si la flota viene y Vm no, será aca- $/{ }^{9}$ bárseme los días de la vida. Yo haré a mi padre $/{ }^{10}$ que busque una lisensia para $\mathrm{Vm}$ y mi $/{ }^{11}$ hijo Antón. Senora, de los siem pesos merca- ${ }^{12}$ rá de vestir, porque por acá vale caro el vestido $/{ }^{13}$ y lo que sobrare será para el matalotajes, $/{ }^{14}$ que los fletes yo los pagare acá. Y mire que $/^{15}$ no trayga manto de arnascote, que no se $/{ }^{16}$ uza por acá si no es de burata, ni cosa de paño, $/{ }^{17}$ digo de sayas, sino para la mar, y una rropilla/ ${ }^{18}$ de valleta. Aý escrivo a mi padre que me $/^{19}$ embíe unos basines y unas muelas para des- $/^{20}$ que Vm venga, poner mi tienda, porque si Dios ${ }^{21}$ trae com bien a Vm, en llegando, luego ${ }^{22}$ la emos de poner, luego a la ora, sin más de- $/^{23}$ tener. Señora, no se m'escuze ni m'eche $/{ }^{24}$ ahaque ninguno, porque no abrá achaque que ${ }^{25}$ yo crea. Aquí quiero ver la voluntad que $\mathrm{Vm} \mathrm{me} /{ }^{26}$ tiene e suplícole que no aya falta en esto, ya digo ${ }^{27}$ que Botello vaya, y mi maeso, qu'ellos y mi padre ${ }^{28}$ (Fol. 2) lo negosiarán todo muy bien. A señor y se- $/^{1}$ ñora, que no le pongan mal corasón, sino que $/ 2$ le animen en lo que pudieren. Alonso D’Ávila/ ${ }^{3}$ esta en Jusexaca con su tienda, que ganará/ ${ }^{4}$ muy bien de comer, y Diego de Ávila esta bue- $/^{5}$ no de salud, bendito Dios. Allá l'enbía a señor $/{ }^{6}$ siem e pesos. Y con esto seso, y no de $\operatorname{rrogar}^{7}$ a Dios que la vea yo en esta tiera con salud, para/ ${ }^{8}$ que a mí me dé doblado contento i amén. $/^{9}$

Al señor Alexos Martín y a la señora su mujer $/^{10}$ le dará mis bezamanos y a señor y señora, por el $/{ }^{11}$ consigiente, a Maria d'Ábila le dará mis $/{ }^{12}$ besamanos, que plega dios que la vea yo muy $/^{13}$ bien empleada. Amén. A todos los parien- $/{ }^{14}$ tes y amigos les dará mis encomiendass $/{ }^{15}$ y a Juan d'Ávila si quisiere venir, que $/{ }^{16}$ me hará mersed. $/^{17}$

Mire Vm que, si no viene, me prenderán por casado, ${ }^{18}$ me costará lo que no tengo. $/{ }^{19}$

El que más que a sí desea ver a $\mathrm{Vm} /{ }^{20}$

Bartolomé de Morales (Fol. 3)

\section{IG 2056, N37}

Señora hermana:

Avéis de saber que nuestra madre es muerta y/ $/^{1}$ murió este año de 1573 ; murió por hebrero a $/^{2} 4$ del mes y ella tenía propuesto de enbiar por $/^{3}$ uos y por vuestro marido y fue Dios servido de a- $/^{4}$ taxarlo con su muerte, de lo qual vos puede $/{ }^{5}$ pesar muy mucho, tanto como a mí, pues tan- $/^{6}$ bién os quería y tanbién estávades casada. $/^{7}$

Ella dexó çierta hazienda para vos y para ${ }^{8}$ mí, la qual est[á] en manos de albaçeas y ${ }^{9}$ no la quieren dar a mí ni a nayde (sic) sy vos y $/{ }^{10}$ vuestro marido, Lope de Torres, no benís a pe- $/^{11}$ dyrla y avnque quisiéredes que vuestro ma- $/{ }^{12}$ rido venga por ella, no se le dará avnque $/{ }^{13}$ más poderes trayga, porqu'está en el $/{ }^{14}$ testamento que a bos y a él juntos se en$/{ }^{15}$ tregue, porque entendía que os que- $/{ }^{16}$ daríades en esta buena tierra y más $/{ }^{17}$ biendo el buen aparejo de bibir en ella en $/{ }^{18}$ más descanso que allá y con menos $/{ }^{19}$ neçesidad. 
Por eso, señora hermana, no de- $/^{20}$ xéis de benir vos y buestro marido en la $/^{21}$ prymera flota que se hiziere, a poner ${ }^{22}$ en rrecaudo vuestra hazienda, porque $/{ }^{23}$ en poder ajeno cada día valdrá ${ }^{24}$ menos y para vuestro biaje yo qujsiera ${ }^{25}$ enbiaros algo, avnque fuera de $10 /{ }^{26}$ que es mío, pero no pude acabar que ${ }^{27}$ se me diese. Procurá de benir con lo que ${ }^{28}$ (Fol. 3) tubiéredes en qualquier nabío que ${ }^{1}$ para esta probincia de Nueba España bynjere, $/^{2}$ que si en algo os acreditaren para $/^{3}$ vuestro flete, yo digo que lo pagaré $/^{4}$ vn mes después que seáis benjdos $/{ }^{5}$ a estas partes syn njnguna falta, ${ }^{6}$ y en qualquiera nabío que os quiráis ${ }^{7}$ fletar, sabiendo que es cosa mía, $f^{8}$ os traerán con todo rregalo porque $/^{9}$ todo (sic) los más de los maestros son $/{ }^{10}$ mjs conoçidos y amigos, que los $/{ }^{11}$ rregalo yo aquí en este puerto de la $/{ }^{12}$ Beracruz y los siruo con mis carretas $/{ }^{13}$ y criados en llevar sus haziendas $/{ }^{14}$ a tierra adentro con mjjor volun- $/^{15} \operatorname{tad}$ que otros. Y si acaso por ventur[a] $\left.\right|^{16}$ no halláredes qujen os trayga por $/^{17}$ cosa mía, procuraréis de preguntar $/{ }^{18}$ por vn mançebo que fue en la cara- $/{ }^{19}$ bela de aviso d'esta flota, que se 1 lama $/{ }^{20}$ Hernando de Serralta, y deçilde que, por ${ }^{21}$ señas que su tío Gaspar de Serralta/ ${ }^{22}$ se quedó en estas partes, que os traiga, ${ }^{23}$ que yo lo serviré en todo lo que él acá me ${ }^{24}$ mandare, allende de pagarle todo lo/ ${ }^{25}$ que otro le pagare. Y d'esto me haréis $/^{26}$ merced de no dexar de benir y poner toda la $/{ }^{27}$ delygencia posible, que demás de ${ }^{28}$ cobrar vuestra hazienda por aber enten- $/^{29}$ dido vuestra neçesidad, tendréis parte $/{ }^{30}$ en la mía y no pongáis ynconbynjente ${ }^{31}$ (Fol. 4) en la benjda por falta de posibilidad, $/^{1}$ pues como digo, qualquiera maestre $/^{2}$ os faboreçerá por $[\ldots$ ? $]$ speto. $/{ }^{3}$ Lleba esta carta vn onbre que se llama ${ }^{4}$ Pedro de Rutia, que a de bolber y es biz- $/^{5}$ caýno y estubo en mj casa muchos $/^{6}$ días y se lo encomendé mucho que os $/^{7}$ la diese y a de bolber, a lo que me $/^{8}$ dixo. Y con esto, esperando vuestra benjda, $/^{9}$ no digo más syno que Nuestro Señor os trayga $/{ }^{10}$ como yo deseo.

A Segura y a su hija $/{ }^{11}$ daréis mis encomjendas y a todos $/^{12}$ los conocydos.

De la Beracruz y de $/{ }^{13}$ março $18 / 1574 . /^{14}$

Vuestro verdadero hermano, que vuestro bien desea.

Bartolomé Ruyz (Fol. 5)

\section{IG 2059, N69}

(El expediente es a favor de Lázaro González, hijo de Antón Criado, aunque la carta es de éste último a Marcos de la Reina, su hermano, vecino de Sevilla, como también lo es Lázaro Glez.)

\section{Señor ermano:}

Vna de vuestra merced recibí en casa de Juan López y con ella/ ${ }^{1}$ todo contento en saber de su salud: Nuestro Señor se la dé $/^{2}$ sienpre, amén. Dízeme por su carta que no vie- $/^{\beta}$ ne mj hijo por aca por no tener posible para ello; $/^{4}$ no es cavsa bastante eso, sino la poca gana que $/{ }^{5}$ de verme tiene. Tengo entendido no me conosce, $/^{6}$ porque todos quantos quieren venjr a esta tierra $/^{7}$ vienen sin dinero, pues no es él tan maníaco $/{ }^{8}$ que si quisiese venjr no lo traerán. Y en $/{ }^{9}$ lo demás, está el día de oj el mundo de suerte $/{ }^{10}$ que no ay que fiar de nadie para enbiar dinero, $/{ }^{11}$ pero ya lo vbiera enbiado si a ello me atreviera. ${ }^{12}$ Eme holgado mucho en saber es buen ofiçial $\mathrm{y} /{ }^{13}$ averse aplicado a la virtud como todo onbre de $/{ }^{14}$ bien lo deve hazer; muj gran contento sería ${ }^{15}$ para mí verlo acá. 
El que la presente lleva $/{ }^{16}$ es vn frayle de San Francisco muj onrrabr'él/ ${ }^{17}$ me prometió de hazer de suerte que pase a esta/ ${ }^{18}$ tierra; tengo entendido lo hará. Si al presente me $/{ }^{19}$ hallara con dinero, no dexara de enbiar algo/ ${ }^{20}$ para ayuda, mas digo verdad que a dado en $1 \mathrm{a} /{ }^{21}$ tierra, entre los naturales d'ella, tan gran pes- $/^{22}$ tilençia que no ay qujen conpre trigo ni maýs ${ }^{23}$ ni otra cosa qu'el onbre tenga, que si no fuera $/{ }^{24}$ esto, yo enbiara, como digo, con qué se vinjera. ${ }^{25}$ (Fol. 11)

De lo que vuestra merced dize de la muerte de nuestra/ ${ }^{1}$ madre y ermanos, rrecibí pena: Nuestro Señor los $11 \mathrm{e}-/^{2}$ ve a su santa gloria y perdone sus pecados y a ${ }^{3}$ vuestra merced guarde, con que sienpre se acuerde de ha- $/^{4}$ zer bien por ellos, que lo mjsmo hago yo acá.

No ay $/{ }^{5}$ más que le hazer saber. Nuestro Señor me lo dexe ver co- $/^{6}$ mo yo deseo. A mj hijo me encomiende mucho y que aya $/{ }^{7}$ esta por suya y que le rruego yo haga lo qu'el frayle le di- $/^{8}$ xere y, si ser pudiere traer consigo a su primo $/{ }^{9}$ Cristóval de Sanabra, holgaré d'ello, que para moços $/{ }^{10}$ es buena tierra. A la señora mj ermana y a nuestros sobri- $/^{11}$ nos beso las manos muchas vezes y lo mjsmo mj mujer, $/^{12}$ se le encomienda mucho.

$\mathrm{Y}$ en esto de mj hijo no aya $/{ }^{13}$ otra cosa sino que haga lo qu'el padre le dixere por- $/^{14}$ qu'él dará orden como vengan.

De Queretaro y de he- $/{ }^{15}$ brero a 2 de 1577 años

Besa las manos a Vm

Antón Criado (Fol. 12)

\section{IG 2063, N27}

Illuestre señora:

La de Vm rrecibí en fecha a diez y seys de março de ochenta y $/^{1}$ quatro y çierto que quando me la dieron que entendí que esta- $/^{2}$ ba Vm y su ermana en el puerto de Caballallos (sic), que $/^{\beta}$ me abía alegrado tanto que no se lo podré senyficar y tan- $/^{4}$ bjén me holgué, ya que esto no fue saver que tenían salud y $/^{5}$ pesóme mucho de que $\mathrm{Vm}$ no se bjnjese y qujera estar $/^{6}$ en esa tierra no debjéndolo hazer, porque desde el día $/^{7}$ que Dios fue servjdo llebarse a mj hermana, no abía de $/^{8}$ estar más en ella, pues no tiene lo que a su calidad rre- $/^{9}$ quyere, nj parientes que puedan aqudir a rreme- $/{ }^{10}$ diallas en nada. Y así, pues les enbiaba con qué poder be- $/^{11}$ njr, no abía de hazer otra cosa, porque si bjnjera y obyera/ ${ }^{12}$ hecho lo que tanto deseo y estubiera casada muy bjen/ ${ }^{13}[\mathrm{co}$ ?]n vn mercader amjgo mío muy honrrado y así ten- $/^{14} \mathrm{~g}^{\mathrm{l}}$ conçertado con él que aguarde a la buelta de los na- $/{ }^{15}$ víos, porque yo enbío a $\mathrm{Vm}$ a rrogalla que por mj con- ${ }^{16}$ tento tome este trabaxo y para ello enbío que den a/ ${ }^{17} \mathrm{Vm}$ qujnjentos ducados y más todo lo que fuere $/{ }^{18}$ menester, porque venga vjen adereçada de bes- $/{ }^{19}$ tidos y otras cosas. Y para ello se a de aqudir a $/{ }^{20}$ Juan Babtista Valdirón, en cal de Francos, que él lo da- ${ }^{21}$ rá luego, porque ya tiene orden mía y déle de $/^{22}$ todo $\mathrm{Vm}$ carta de pago y abísele de las perso- $/^{23}$ nas que vendrán, porque cuando lleguen a Sebilla/ ${ }^{24}$ les tenga hecho matalotaxe y buscado la nao ${ }^{25}$ mexor que bjnjere, porque yo se lo escribo, que a mj quenta ${ }^{26}$ (Fol. 3) flete y todo lo demás lo haga. Y Vm se trayga su/ ${ }^{1}$ negrita ya que no le quedó otra hazienda, que para el ca- $/^{2}$ mjno de mar y tierra la a mucho menester, y si quj- $/^{3}$

\footnotetext{
${ }^{\imath}$ Es eso lo que pone, teng, falta la o.
} 
siere benjr su ermana Mariana, Vm la trayga, $/{ }^{4}$ que tan bien rreçibida será como Vm, y si algunas $/^{5}$ criadas truxeren, que serán menester dos, las hagan $/{ }^{6}$ que se obliguen que servirán dos o tres años llegados a es- $/^{7}$ ta tierra, porque de otra suerte no qunplirán cosa, $/^{8}$ y para todo se enbíe al consexo de Yndias por liçen- $\rho^{9}$ çias y, llegados a la çibdad de Truxillo, escriba $/{ }^{10} \mathrm{Vm}$ de su llegada con el que bjnjere a traer el plie- $/{ }^{11}$ go del rrey a esta avdiencia, porque les tenga en' $1 / /^{12}$ golfo todo rreca de bestias y rrefresco que será $[\mathrm{n}] \mathrm{e}-\mathrm{I}^{13}$ çesario. Y, porque entiendo que en ello no abrá falta, no $/{ }^{14}$ digo más de que quedo bueno, suplicando a Nuestro Señor ${ }^{15}$ los trayga con bjen y dé tan buen biaxe como yo $/{ }^{16}$ deseo. Y de la villa de la Trenjdad, a vejnte y çinco $/{ }^{17}$ de abril de ochenta y çinco. $/^{18}$

Ylluestre señora

Beso las manos a Vm, su tío, que todo su bien desea.

Francisco de Mesa (Fol. 4)

\section{IG 2065, N47}

Después que di la buelta de la China, tengo scriptas $/{ }^{1}$ muchas en todas las ocasiones que se an ofresçido y dado/ ${ }^{2}$ quenta de mis trabajos y pérdidas: Dios sea loado $/ 3$ por todo, que con tantas ventajas me a querido re- $/{ }^{4}$ galar, pues de cinco años a esta parte son más de ${ }^{5}$ çien mill pesos los que he perdido y pudiera sacar de $/{ }^{6}$ lo que me an lleuado ingleses i la mar. $I^{7}$

Muchos años a que no he uisto carta de $\mathrm{Vm}$, avnque $/{ }^{8}$ por vn capítulo de vna del señor Diego Cauallero entendí auías tomado $/^{9}$ estado con mi señora doña Casilda de Bustamante, que no $/{ }^{10}$ me dio poco contento auernos cabido tam buena suerte ${ }^{11}$ y puedo deçir con verdad que nunca sentí la pérdida $/{ }^{12}$ de mi haçienda sino después que lo entendí, porque ${ }^{13}$ quisiera yo yr a seruir con toda ella a quien tam $/{ }^{14}$ bien lo mereçe y que fuera señora de toda, y sobre esto/ ${ }^{15}$ ia tengo scripto largo en las fragatas y navíos de $/{ }^{16}$ auiso que an salido. Deseo que se ayan reçebido. Tam- $/{ }^{17}$ bién escreuí a mi señora doña Casilda, a quien beso las manos $/{ }^{18}$ mill vezes. $/{ }^{19}$

Hermano, io estoy ia tan cansado en estas partes que ${ }^{20}$ me pareçe es temeridad querer tentar más la ${ }^{21}$ fortuna, pues Dios no se deue deservir de ello ${ }^{22}$ (Fol. 21) y veo a la clara que quanto más trabajo y más me desvelo/ ${ }^{1}$ por lleuar algo, más me lo va quitando en donde $/^{2}$ él sabe. $Y$ así, estoy determinado de dar mano a esta tierra $/^{\beta}$ y yr a morir entre essos bardales, que segund los muchos $/{ }^{4}$ infortunjos y trabajos en que me e bisto, me serán de gran con $-/^{5}$ tento, y para lo que resta de la uida poco es menester. $\mathrm{Vm} /{ }^{6} \mathrm{me}$ escriua largo $\mathrm{i}$ auise de su pareçer, porque ese será el $/^{7}$ más açertado y el que io escojeré. Y asta que vea carta de $/^{8} \mathrm{Vm}$, estaré siempre con cuidado y pues estoy a la puerta/ ${ }^{9}$ de la Nueba Epaña (sic), con qualquiera que a ella venga que se le $/^{10}$ den las cartas serán seguras y las más por la uía del $/^{11}$ señor Juan Carrillo a Sevilla./ ${ }^{12}$

En esta flota jeneral, Martín Pérez de Olacaual embió çien $/{ }^{13}$ pesos consignados a Juan Carrillo para que los embíe a $\mathrm{Vm}$, que ${ }^{14}$ son de Mari Sauín, mujer que fue de Hernán Sánchez de A- $/^{15}$ paricio, que son de lo que dexó su hijo Juan. Supplico a Vm/ ${ }^{16}$ que dé orden para que los aya y se rreçiba recado del reçibo/ ${ }^{17} \mathrm{y}$ a de mandar deçir veinte missas en la iglesia de Balcaba $/{ }^{18}$ y otras veinte en Sant Felipes y diez en Sant Martín. Vm le a- $/{ }^{19}$ visará de todo $\mathrm{y}$, si estubiere en Estremadura, podrá $\mathrm{Vm} /{ }^{20}$ auisarla y que embíe poder y 
recado a Juan Carrillo/ ${ }^{21}$ con carta de Vm para que se los dé. Y guarde Nuestro Señor ${ }^{22}$ a Vm muchos años como yo deseo. $/^{23}$

En el pueblo de Sant Miguel de Roças bibe vna señora que/24 se llama Catalina Ezquerra, casada que fue con Cristóval ${ }^{25}$ Sánchez de Roças, el qual murió viniendo de la China y dexó $/{ }^{26}$ haçienda, la qual está empoder (sic) de Hernando Pacheco y antes ${ }^{27}$ que muriese me escreuió que fuese su albaçea con el dicho Pa- ${ }^{28}$ checo. Es menester que para que se le pudan (sic) embiar ${ }^{29}$ (Fol.22) estos dineros embíe poder para mí y para el dicho/ ${ }^{1}$ Hernando Pacheco. En otra tengo escripto a Vm y a ${ }^{2}$ la dicha con vn vezino de Balmaseda que me $/^{\beta}$ prometió de yr a ver a Vm y si acaso no llegare $/^{4}$ allá, por esta carta la auise $\mathrm{Vm}$ a la dicha $\mathrm{Ca}-/^{5}$ talina Ezquerra y venga lo más presto que $/{ }^{6}$ ser pueda. De la isla y puerto de Sant Juan de Vlúa, a 12 de junyo de $89 . /^{7}$

A nuestra hermana encomiendo mucho por $/^{8}$ amor de Nuestro Señor, hasta que yo vaya que $/{ }^{9}$ quite de esse cuidado. $/^{10}$

Joan Çorrilla de la Concha (Fol. 23)

\section{IG 2067, N35}

(Juan de Robles a su hermano Jaime de Robles, vecino de Valladolid)

Hermano de mi coraçón:

Después que salí de esa tierra, $/{ }^{1}$ e sido tan desdichado que nunca e tenido más de dos cartas $/^{2}$ suyas: la vna con el señor Aparicio de Artiaga y la otra con $/^{3}$ vn pliego de mi primo Juan Rubio, que me a tenido con $/{ }^{4}$ harto cuidado, entendiendo si está con salud o qué aya/ ${ }^{5}$ hecho Dios de él. En la última me avisó que hará lo/ ${ }^{6}$ que le tengo suplicado de benirse y que lo tenía ya $/^{7}$ acavado con mi hermano. Por amor de Dios le rruego no ${ }^{8}$ deje de acerlo, pues sabe lo que yo lo deseo y que lo pa- $/{ }^{9}$ sará mejor que allá, pues tengo con qué faborecerles $/{ }^{10} \mathrm{y}$ es todo para ellos y no tengo otros deudos ni parientes $/{ }^{11} \mathrm{y}$ si se determinare a hacerlo, en Sebilla en casa de el $/{ }^{12}$ barbero de el cardenal que se llama Aste de Fuentes $/^{13}$ le dirán de mi buen amigo Gerónimo de Paz y él dará $/{ }^{14}$ orden para que se abíe y benga acomodado, que ${ }^{15}$ tiene mucho conocimiento en esta ciudad y allá mu- ${ }^{16}$ chos amigos, y e savido que se lo a escrito de mi parte. $/{ }^{17}$ No rrepare en nada que Dios me ayudará y esta tierra $/{ }^{18}$ tan buena es como la nuestra, pues que Dios nos a dado a- $/{ }^{19}$ quí más que allá y podremos pasar mejor. Las ${ }^{20}$ tierras que allá tiene deje bendidas y todo lo de- ${ }^{21}$ más, que no será menester, y la casa qu' $[\mathrm{e}] \mathrm{ra}$ de/ ${ }^{22}$ mi agüela la deje al monesterio de los frailes ${ }^{23}$ Franciscos para que la vendan o hagan lo que quisieren. ${ }^{24}$ (Fol. 3) Dé limosna porque Dios les dé buen viaje. A Juanico me $/^{1}$ traigan rregalado, que lo deseo ber lo que no podré en- $/^{2}$ carecer. Aquí me an traído muchos casamientos para ${ }^{3}$ Pretonila, la sobrina de Rubio, que como sabe que- $/^{4}$ dó en mi poder y yo por su curador: no lo e efetuado $/^{5}$ por aguardarle y tratar de cierta cosa que creo $/{ }^{6}$ nos a de estar vien a todos, según yo lo deseo, no $\mathrm{creo}^{7}$ será. Nuestro Señor lo haga como puede. A todos los ami- $/^{8}$ gos dará mis encomiendas y, porque le es- $/^{9}$ pero por otros y escrebiré más largo en el na- $/^{10}$ vío de abiso, no más de que Nuestro Señor le traiga con $/{ }^{11}$ bien y a mi hermano y sobrinos, a quien beso/ ${ }^{12}$ mill beçes las manos. De esta ciudad de Los Án- $/^{13}$ jeles a 20 de agosto de 92 años..$^{14}$

Su hermano, que su bien y salud desea. 
Juan de Robles (Fol. 4) 
